\title{
SISTEM PENDUKUNG KEPUTUSAN PENENTUAN BONUS SALES DI PT.MASTER DUMAI DENGAN METODE $S A W$ (SIMPLE ADDITIVE WEIGHTING)
}

\author{
Ikbal Patisera ${ }^{1}$, Rahmat Hidayatullah ${ }^{2}$ \\ ${ }^{1,2}$ Sekolah Tinggi Manajemen Informatika dan Komputer (STMIK) Dumai \\ Jl. UtamaKarya, Bukit Batrem II Kota Dumai- Riau \\ Email:patisera.ikbal@yahoo.co.id
}

\begin{abstract}
ABSTRAK
Sales berperan penting dalam proses penjualan di suatu perusahaan khususnya dalam bidang eletronik. fungsi sales antara lain melaksanaan promosi suatu produk perusahaan sekaligus menjual produk tersebut. Sebagai karyawan para sales di tuntut untuk menghasilkan prestasi kerja yang baik. hasil kerja sales akan di wujudkan dalam bentuk pencapaian target tertentu. untuk memenuhi target tersebut perusahaan juga seringkali memberikan bonus untuk memacu kinerja dan produktifitas kerja sales. bonus yang diterima oleh sales diharapkan semakin meningkatkan motivasi sales dalam memenuhi target penjualan yang diinginkan oleh perusahaan tersebut. Dalam pelaksaannya, PT.Master Dumai telah menerapkan suatu penentuan bonus sales dalam jangka waktu satu tahun sekali. Proses penentukan bonus sales masih terdapat kendala-kendala diantaranya, target penjualan yang harus di capai masih di hitung secara manual dan banyaknya perbandingan variable yang harus diuji sehingga sulitnya seorang manager dalam menentukan tiap sales yang pantas menerima bonus dari hasil kinerjanya.
\end{abstract}

Kata Kunci : SPK, Metode SAW

\section{PENDAHULUAN}

Sales berperan penting dalam proses penjualan di suatu perusahaan khususnya dalam bidang eletronik. fungsi sales antara lain melaksanaan promosi suatu produk perusahaan sekaligus menjual produk tersebut. Sebagai karyawan para sales di tuntut untuk menghasilkan prestasi kerja yang baik. hasil kerja sales akan di wujudkan dalam bentuk pencapaian target tertentu. untuk memenuhi target tersebut perusahaan juga seringkali memberikan bonus untuk memacu kinerja dan produktifitas kerja sales. bonus yang diterima oleh sales diharapkan semakin meningkatkan motivasi sales dalam memenuhi target penjualan yang diinginkan oleh perusahaan tersebut.

Dalam pelaksaannya, PT.Master Dumai telah menerapkan suatu penentuan bonus sales dalam jangka waktu satu tahun sekali. Proses penentukan bonus sales masih terdapat kendala-kendala diantaranya, target penjualan yang harus di capai masih di hitung secara manual dan banyaknya perbandingan variable yang harus diuji sehingga sulitnya seorang manager dalam menentukan tiap sales yang pantas menerima bonus dari hasil kinerjanya.

Oleh karena itu, perlu dibuat sebuah sistem pendukung keputusan (SPK) penentuan bonus sales. Dengan adanya sistem ini, diharapkan dapat membantu manager dalam menentukan bonus sales pada PT. Master. Salah satu metode untuk mendukung suatu sistem penentukan bonus sales dengan metode simple edditive weighting $(S A W)$, dimana metode ini merupakan metode pembilangan terbobot atau metode yang memberikan kriteriakriteria tertentu yang memiliki bobot nilai masingmasing sehingga dari hasil penjumlahan bobot tersebut akan diperoleh hasil yang menjadi keputusan akhirnya. . Kriteria yang ditetapkan dalam studi kasus ini adalah target, kehadiran, prilaku, etos kerja. Dengan demikian manager dapat menentukan besarnya bonus sales yang dapat ditargetkannya

Data adalah kenyataan yang mengambarkan suatu kejadian-kejadian dan kesatuan nyata. 
Kejadian-kejadian adalah suatu yang terjadi pada saat tertentu. Data adalah bentuk yang masih mentah yang belum dapat bercerita banyak sehingga perlu diolah lebih lanjut. Data diolah melalu suatu model untuk menghasilkan informasi. (jogiyanto, 2009:h.8)

Informasi adalah data yang diolah menjadi bentuk yang lebih berguna dan lebih berarti bagi yang menerimannya. (jogiyanto, 2009:h.8) sistem pengolahan informasi mengolah data menjadi informasi atau lebih tepatnya mengolah data dari bentuk tak berguna menjadi berguna bagi penerimanya. Sumber informasi adalah data. Data merupakan kenyataan yang menggambarkan suatu kejadian serta merupakan suatu bentuk yang masih mentah yang belum dapat bercerita banyak sehingga perlu diolah lebih lanjut melalui suatu model untuk menghasilkan informasi.

sistem adalah sejumlah komponen yang saling berinteraksi yang artinya saling bekerja sama membentuk satu kesatuan.komponen-komponen sistem atau elemen-elemen sistem dapat berupa suatu subsistem atau bagian-bagian dari sistem. (jogiyanto, 2009 :h.4)

HIPO (Hirarchy Plus Input - Proses output)merupakan teknik untuk mendokumentasikan pengembangan suatu sistem yang dikembangkan oleh IBM. HIPO sebenarnya adalah alat dokumentasi program. akan tetapi sekarang, HIPO juga banyak digunakan sebagai alat desain dan teknik dokumentasi dalam siklus pengembangan sistem. HIPO berbasis pada fungsi, yaitu tiap - tiap modul di dalam sistem digambarkan oleh fungsi utamanya (Hanif Al Fatta,2007: h.147).

Menurut Kusrini (2007) dalam Jurnal Leni Natalia Zulita (2013), Sistem pendukung keputusan atau Decision Support System (DSS) merupakan system informasi interaktif yang menyediakan informasi, pemodelan, dan pemanipulasian data . Sistem itu digunakan untuk membantu pengambilan keputusan dalam situasi yang semiterstruktur dan situasi yang tidak terstruktur, dimana tak seorang pun tahu secara pasti bagaimana keputusan seharusnya dibuat. DSS biasa nya dibangun untuk mendukung solusi atas suatu masalah atau untuk mengevaluasi suatu peluang. DSS yang seperti itu biasa disebut aplikasi DSS.

Menurut Henry Wibowo (2009) dalam Jurnal Leni Natalia Zulita (2013), Fuzzy Multiple Attribute Decision Making (FMADM) adalah suatu metode yang digunakan untuk mencari alternatif optimal dari sejumlah alternatif dengan kriteria tertentu. Inti dari FMADM adalah menentukan nilai bobot untuk setiap atribut, kemudian dilanjutkan dengan proses perankingan yang akan menyeleksi alternatif yang sudah diberikan. Pada dasarnya, ada 3 pendekatan untuk mencari nilai bobot atribut, yaitu pendekatan subyektif, pendekatan obyektif dan pendekatan integrasi antara subyektif dan obyektif. Masingmasing pendekatan memiliki kelebihan dan kelemahan. Pada pendekatan subyektif, nilai bobot ditentukan berdasarkan subyektifitas dari para pengambil keputusan, sehingga beberapa faktor dalam proses perankingan alternatif bisa ditentukan secara bebas. Sedangkan pada pendekatan obyektif, nilai bobot dihitung secara matematis sehingga mengabaikan subyektifitas dari pengambil keputusan.

Menurut Kusumadewi (2007) dalam jurnal Liza Natalia Zulita (1858-2680), metode $S A W$ (Simple Additive Weighting) sering dikenal dengan metode penjumlahan terbobot. Konsep dasar metode $S A W$ adalah mencari penjumlahan terbobot dari rating kinerja pada setiap alternatif dari semua atribut.

\section{METODOLOGI PENELITIAN}

Kerangka penelitian yang di gunakan dalam penelitian ini adalah sebagai berikut :

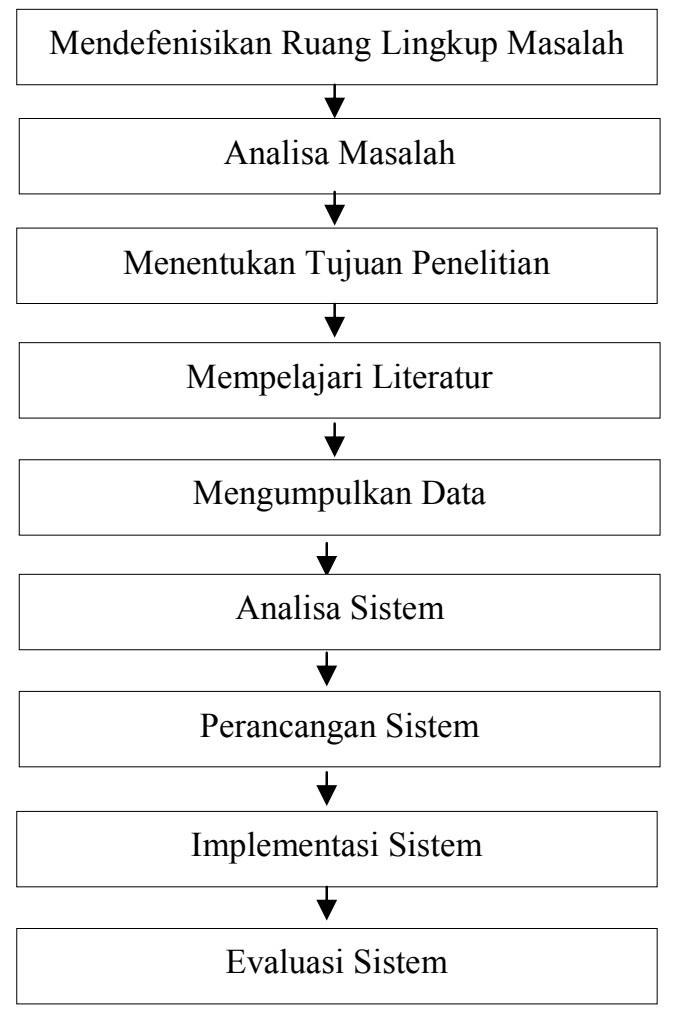

Gambar 1. Kerangka Penelitian 
I N F ORM A I K A

Jurnal Informatika, Manajemen dan Komputer, Vol. 8 No. 2 , Desember 2016

eISSN : 2580-3042

pISSN : 1979-0694

\section{HASIL DAN PEMBAHASAN}

\section{a. Aliran Sistem Informasi (ASI) sedang berjalan}

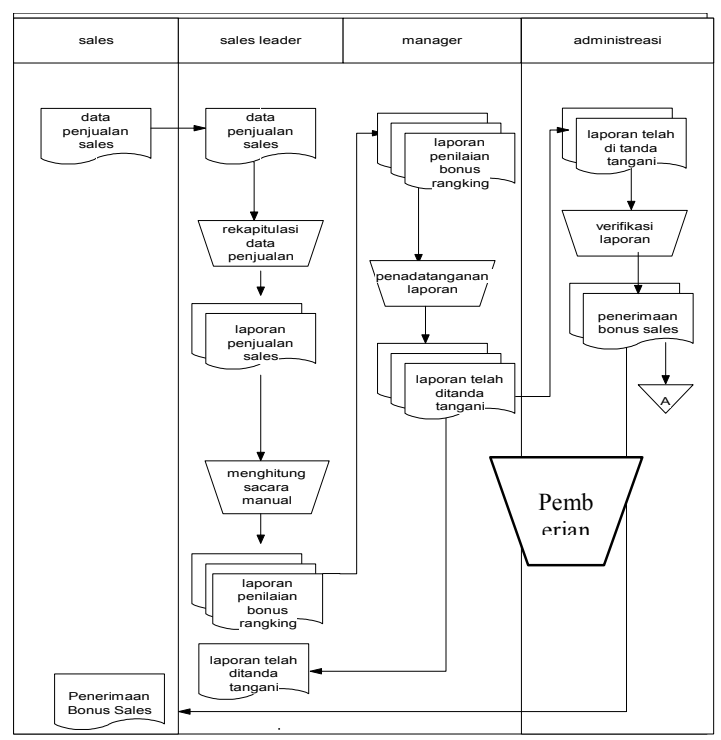

Gambar 2. ASI Sedang Berjalan

\section{b. Aliran Sistem Informasi (ASI) Baru}

Aliran sistem informasi pemberian bonus pada PT. Master yang baru tidak mengalami banyak perubahan dari sistem yang lama, hanya saja dalam proses pembobotan dan pembuatan laporan bonus Sales.

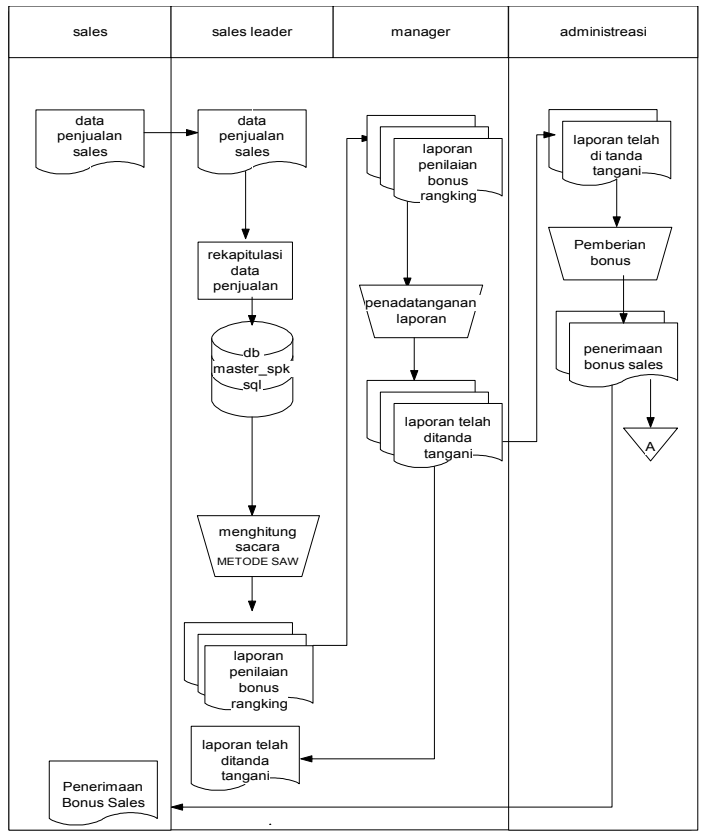

Gambar 3. ASI Baru

\section{c. Contex Diagram}

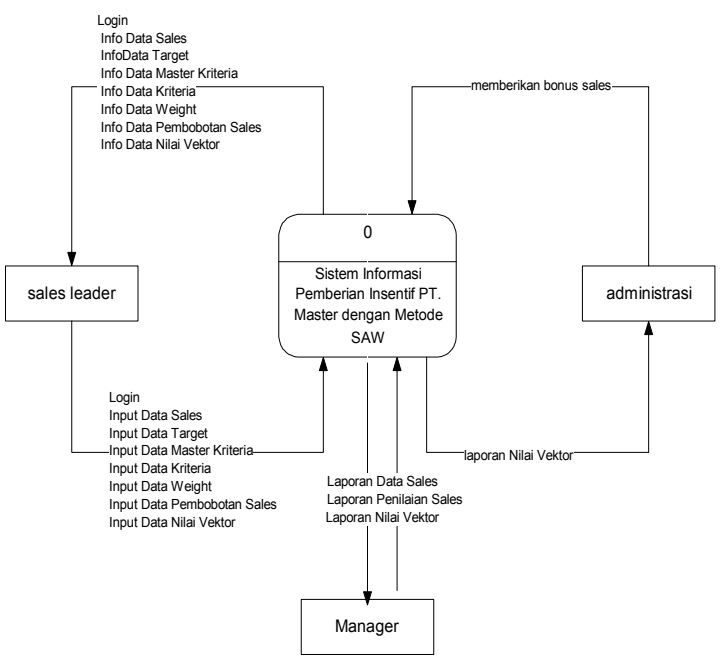

Gambar 4. Contex Diagram

\section{d. Analisa Perhitungan Manual Metode $\boldsymbol{S A W}$}

Berdasarkan dari penelitian yang dilakukan penulis, berikut penerapan dari SPK yang digunakan dalam penyeleksian pemberian insentif pada PT. Master menggunakan Metode Simple Additive Weighting.

A. Alternatif Perangkingan Pemberian insentif berdasarkan jumlah nominal insentif (bonus)

Pada deskripsi perangkingan pemberian isentif penulis melakukan analisis terhadap 3 orang Sales sebagai sampel pada peneltian ini yaitu :

1. Rizky Al Farisi

2. Dian Nirmala

3. Joni Sihombing

B. Kriteria Penilaian

Adapun kriteria sebagai perbandingan adalah seperti dibawah ini :

1. Target $(\mathrm{C} 1)$

2. Kehadiran (C2)

3. Prilaku (C3)

4. Etos Kerja (C4)

Dari masing-masing kriteria tersebut memiliki sub criteria yang akan ditentukan bobot-bobotnya. Pada bobot terdiri dari lima bilangan, yaitu baik sekali, baik, sedang, cukup, dan rendah seperti terlihat pada tabel 1 . 
I N F O R M T IK

Jurnal Informatika, Manajemen dan Komputer, Vol. 8 No. 2 , Desember 2016

eISSN : 2580-3042

pISSN : 1979-0694

Tabel 1. Tabel Bobot

\begin{tabular}{|l|c|}
\hline \multicolumn{1}{|c|}{ Kriteria } & Nilai \\
\hline Baik Sekali & 5 \\
\hline Baik & 4 \\
\hline Sedang & 3 \\
\hline Cukup & 2 \\
\hline Rendah & 1 \\
\hline
\end{tabular}

Berdasarkan kriteria dan rating kecocokan setiap alternatif pada setiap kriteria yang telah ditentukan, selanjutnya penjabaran bobot setiap kriteria.

Tabel 2. Target

\begin{tabular}{|l|c|c|}
\hline \multicolumn{1}{|c|}{ Kriteria } & Target & Nilai \\
\hline Baik Sekali & $>=90.000 .000$ & 5 \\
\hline Baik & $>=70.000 .000-<90.000 .000$ & 4 \\
\hline Sedang & $>=50.000 .000-<70.000 .000$ & 3 \\
\hline Cukup & $>=30.000 .000-<50.000 .000$ & 2 \\
\hline Rendah & $\underline{0} \quad \underline{-<30.000 .000}$ & 1 \\
\hline
\end{tabular}

Tabel 3. Kehadiran

\begin{tabular}{|l|l|c|}
\hline \multicolumn{1}{|c|}{ Kriteria } & \multicolumn{1}{|c|}{ Kehadiran } & Nilai \\
\hline Baik Sekali & Selalu Hadir dan Tepat Waktu & 5 \\
\hline Baik & Selalu Hadir & 4 \\
\hline Sedang & Sering Terlambat & 3 \\
\hline Cukup & Sering Tidak masuk & 2 \\
\hline Rendah & Sering Tidak Masuk dan & 1 \\
\hline
\end{tabular}

Tabel 4. Prilaku

\begin{tabular}{|l|l|c|}
\hline \multicolumn{1}{|c|}{ Kriteria } & \multicolumn{1}{c|}{ Prilaku } & Nilai \\
\hline Baik Sekali & Bekerja sesuai SOP & 5 \\
\hline Baik & Dapat Bekerja dengan Tim & 4 \\
\hline Sedang & Kreatif dan inovatif & 3 \\
\hline Cukup & Kurang Bertanggung jawab & 2 \\
\hline Rendah & Emosional dan arogan & 1 \\
\hline
\end{tabular}

Tabel 5. Etos Kerja

\begin{tabular}{|l|lc|c|}
\hline \multicolumn{1}{|c|}{ Kriteria } & \multicolumn{2}{|c|}{ Etos Kerja } & Nilai \\
\hline Baik Sekali & Memiliki Moralitas yang & 5 \\
\hline Baik & Jujur & 4 \\
\hline Sedang & Komitmen & 3 \\
\hline Cukup & Tidak Konsisten & 2 \\
\hline Rendah & Lalai dalam pekerjaan & 1 \\
\hline
\end{tabular}

Tabel 6. Bonus Sales

\begin{tabular}{|l|l|}
\hline Nilai vektor & \multicolumn{1}{|c|}{ Bonus yang diterima } \\
\hline$p=17$ & 2.000 .000 \\
\hline$p=15-<17$ & 1.500 .000 \\
\hline$p=12-<15$ & 1.000 .000 \\
\hline$p=10-<12$ & 500.000 \\
\hline
\end{tabular}

Berikut ini adalah contoh tabel kasus dari perhitungan SAW

Tabel 7. Data Sales

\begin{tabular}{|l|c|l|l|l|}
\hline Nama & Target & $\begin{array}{l}\text { Kehadira } \\
\mathrm{n}\end{array}$ & \multicolumn{1}{|c|}{ Prilaku } & Etos Kerja \\
\hline $\begin{array}{l}\text { Rizky Al } \\
\text { Farisi }\end{array}$ & 85 & $\begin{array}{l}\text { Selalu } \\
\text { Hadir }\end{array}$ & $\begin{array}{l}\text { Kreatif dan } \\
\text { inovatif }\end{array}$ & Komitmen \\
\hline $\begin{array}{l}\text { Dian } \\
\text { Nurmala }\end{array}$ & 75 & $\begin{array}{l}\text { Sering } \\
\text { Terlamba }\end{array}$ & $\begin{array}{l}\text { Bekerja } \\
\text { Sesuai SOP }\end{array}$ & Jujur \\
\hline $\begin{array}{l}\text { Joni } \\
\text { Sihombi }\end{array}$ & 90 & $\begin{array}{l}\text { Selalu } \\
\text { Hadir }\end{array}$ & $\begin{array}{l}\text { Emosional } \\
\text { dan Arogan }\end{array}$ & $\begin{array}{l}\text { Tidak } \\
\text { Konsisten }\end{array}$ \\
\hline
\end{tabular}

Berdasarkan data Sales/sales diatas dapat dibentuk matriks keputusan $\mathrm{x}$, sebagai berikut :

Tabel 8. Rating kecocokan dari setiap alternatif pada setiap kriteria

\begin{tabular}{|c|c|c|c|c|}
\hline \multirow{2}{*}{$\begin{array}{c}\text { Altern } \\
\text { atif }\end{array}$} & \multicolumn{4}{|c|}{ Kriteria } \\
\hline & $\begin{array}{c}\text { Targte } \\
\mathrm{t}\end{array}$ & $\begin{array}{c}\text { Kehad } \\
\text { iran }\end{array}$ & Prilaku & $\begin{array}{c}\text { Etos } \\
\text { Kerja } \\
\end{array}$ \\
\hline $\begin{array}{l}\text { Rizky } \\
\text { Al } \\
\text { Farisi }\end{array}$ & 5 & 4 & 3 & 3 \\
\hline $\begin{array}{l}\text { Dian } \\
\text { Nurma } \\
\text { la }\end{array}$ & 3 & 3 & 5 & 4 \\
\hline $\begin{array}{l}\text { Joni } \\
\text { Sihom } \\
\text { bing }\end{array}$ & 5 & 4 & 1 & 2 \\
\hline
\end{tabular}

Pengambilan keputusan memberikan bobot, berdasarkan tingkat kepentingan masing-masing kriteria yang dibutuhkan sebagai berikut :

Vektor bobot : $\mathrm{W}=[5,5,3,4]$

Membuat matriks keputusan $\mathrm{x}$, dibuat dari tabel kecocokan sebagai berikut :

$$
X=\left\{\begin{array}{llll}
5 & 4 & 3 & 3 \\
3 & 3 & 5 & 4 \\
5 & 4 & 1 & 2
\end{array}\right\}
$$


I N F O R M A I K A

Jurnal Informatika, Manajemen dan Komputer, Vol. 8 No. 2 , Desember 2016

eISSN : 2580-3042

pISSN : 1979-0694

Pertama dilakukan normalisasi matriks $\mathrm{X}$ untuk menghitung nilai masing-masing kriteria berdasarkan kriteria diasumsi sebagai berikut:

$$
\begin{gathered}
V 1=r 11=\frac{5}{\mathrm{M}(5,3,5)}=\frac{5}{5}=1 \\
r 12=\frac{4}{\mathrm{M}(4,3,4)}=\frac{4}{4}=1 \\
r 13=\frac{3}{\mathrm{M}(3,5,1)}=\frac{3}{5}=0,6 \\
r 14=\frac{3}{\mathrm{M}(3,4,2)}=\frac{3}{4}=0,75 \\
V 2=r 21=\frac{3}{\mathrm{M}(5,3,5)}=\frac{3}{5}=0,6 \\
r 22=\frac{3}{\mathrm{M}(4,3,4)}=\frac{3}{4}=0,75 \\
r 23=\frac{5}{\mathrm{M}(3,5,1)}=\frac{5}{5}=1 \\
r 24=\frac{4}{\mathrm{M}(3,4,2)}=\frac{4}{4}=1 \\
V 3=\frac{5}{\mathrm{M}(5,3,5)}=\frac{5}{5}=1 \\
r 32=\frac{4}{\mathrm{M}(4,3,4)}=\frac{4}{4}=1 \\
r 33=\frac{1}{\mathrm{M}(3,5,1)}=\frac{1}{5}=0,2 \\
r 34=\frac{2}{\mathrm{M}(3,4,2)}=\frac{2}{4}=0,5
\end{gathered}
$$

Kedua, membuat normalisasi matriks $\mathrm{R}$ yang diperoleh dari hasil normalisasi matriks $\mathrm{R}$ sebagai berikut :

$$
\left\{\begin{array}{cccc}
1 & 1 & 0,6 & 0,75 \\
0,6 & 0,75 & 1 & 1 \\
1 & \mathrm{R}= & 0,2 & 0,5
\end{array}\right\}
$$

Selanjutnya akan dibuat perkalian matriks $\mathrm{W} * \mathrm{R}$ dan penjumlahan hasil perkalian untuk memperoleh alternatif terbaik dengan melakukan kelayakan nilai terbesar sebagai berikut:

$$
\begin{aligned}
& \mathrm{V} 1=(5)(1)+(5)(1)+(3)(0,6)+(4)(0,75) \\
& =14,8 \\
& \mathrm{~V} 2=(5)(0,6)+(5)(0,75)+(3)(1)+(4)(1) \\
& =13,75 \\
& \mathrm{~V} 3=(5)(1)+(5)(1)+(3)(0,2)+(4)(0,5) \\
& =12,6
\end{aligned}
$$

Dari perhitungan bobot tersebut untuk pemberian insentif pada PT.Master yaitu Rizky Al Farisi yang menjadi rangking pertama dalam urutan insentif yang akan diterima.

\section{Implementasi Sistem}

1. Tampilan Form Setting User

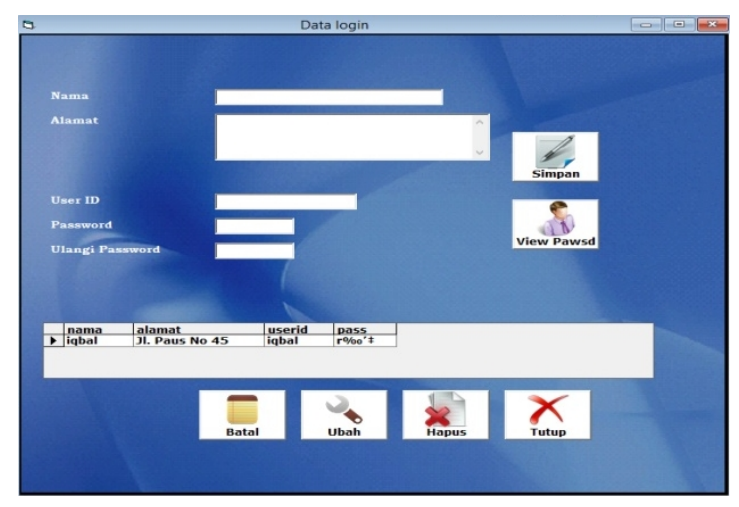

Gambar 5. Form Setting User

2. Tampilan Form Data Master Kriteria

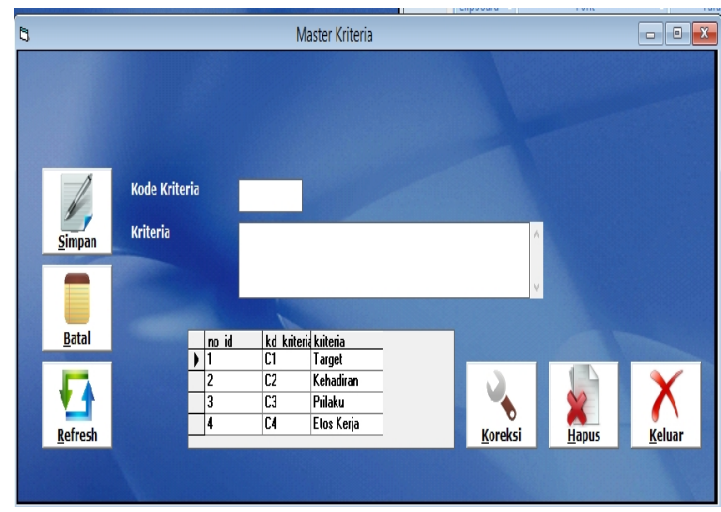

Gambar 6. Form Data Master Kriteria

\section{Tampilan Form Data Kriteria}

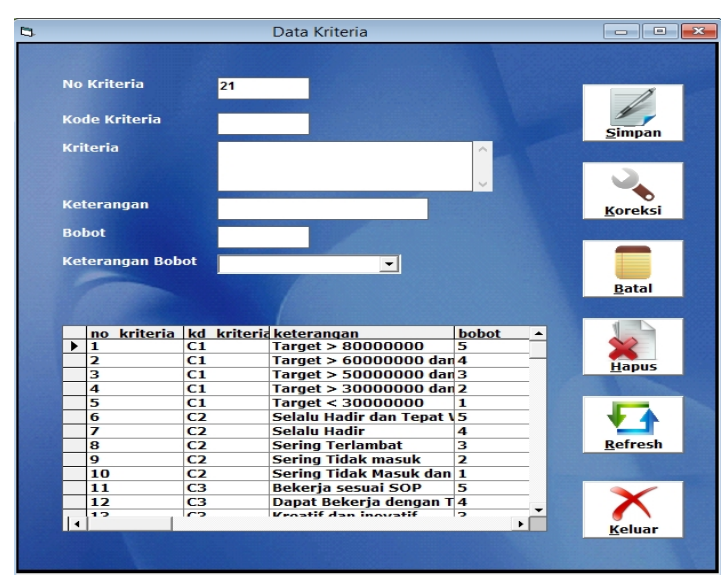

Gambar 7. Form Data Kriteria 
I N F ORM A I K A

Jurnal Informatika, Manajemen dan Komputer, Vol. 8 No. 2 , Desember 2016

eISSN : 2580-3042

pISSN : 1979-0694

\section{Tampilan Form Data weight}

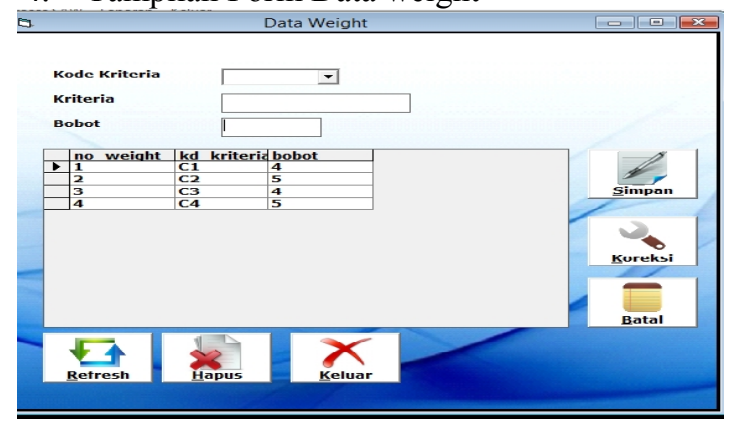

Gambar 8. Form Data Weight

\section{KESIMPULAN}

Berdasarkan penelitian yang telah dilakukan dan dengan perencanaan yang telah dibuat sebelumnya, maka dapat diambil beberapa kesimpulan, yaitu :

1. Proses penyeleksian sales untuk mendapatkan alternatif terbaik adalah diawali dengan proses menganalisa data kriteria yang telah ditetapkan dan masing-masing kriteria tersebut diberikan nilai bobot.

2. Setiap Alternatif diberi bobot berdasarkan hasil target yang meliputi : target, kehadiran, prilaku, dan etos kerja.

3. Hasil akhir berupa nilai vektor, dapat digunakan sebagai pertimbangan dalam mengambil keputusan lebih lanjut terhadap besaran bonus sales dalam penentuan bonus sales.

4. Bobot yang diberikan berdasarkan dari hasil target diberikan nilai bobot kepentingan meliputi: target diberi bobot 5, kehadiran diberi bobot 5, prilaku diberi bobot 3, etos kerja diberi bobot 4 .Pemberian nilai bobot ini dilihat dari pentingnya suatu kriteria yang telah ditentukan oleh sistem penilaian sales.

\section{REFERENSI}

Prof.Dr.jogiyanto.(2009). "Sistem Teknologi Informasi." Yogyakarta. Andi.

Andri kristanto.(2008). "Perancangan Sistem Informasi Dan Aplikasinya." Yogyakarta. Gava Media.

Adi Nugroho.(2011). "Perancangan Dan Implementasi Sistem Basis Data." Yogyakarta. Andi.

Prof.Dr.jogiyanto.(2009). "Analisis Dan Desain." Yogyakarta. Andi.

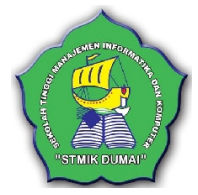

Leni Natalia Zulita.(2013). "Sistem Pendukung Keputusan Menggunakan Metode SAW Untuk Penilaian Dosen Berprestasi." Ed . Jurnal Media Infotama. ISSN: 1858-2680

Edy Winarno ST,M.Eng.(2013). "Belajar Pemograman VB6 Dalam Sekejap.” Jakarta. PT.Alex Media Komputindo.

Dr.Eng.R.H.Sianipar,S.T.,M.Eng(2015)."Pemogram an Database Menggunakan MYSQL." Yogyakarta. Andi.

Surniawan \& Eri Mardiani (2014)."Pengenalan MYSQL." jakarta. PT.Alex Media Komputindo.

Herny Februariyanti dan Eri Zuliarso.(2012). "Rancang bangun sistem perpustakaan untuk jurnal elektronik." Ed . Jurnal teknologi informasi dinamik. ISSN: 0854-9524.

Siti Mujilahwati.(2014). "Diagnosa Penyakit Tanaman Hias Menggunakan Metode Certainty Factor Berbasis Web.” Ed . jurnal teknika. ISSN: 2085-0859. 